\title{
Assessment of Genetic Variability among the Landraces of Little Millets Panicum sumatrense from Different District of Madhya Pradesh
}

\author{
Lalit Prashad Singh Rajput ${ }^{1}$, Keerti Tantwai ${ }^{1 *}$, Sajjan Kumar Pooniya ${ }^{1}$ and Koji Tsuji $^{2}$ \\ ${ }^{1}$ Biotechnology Centre, Jawaharlal Nehru Agricultural University, \\ Jabalpur - 482 004, Madhya Pradesh, India \\ ${ }^{2}$ Faculty and Graduate School of Education, Chiba University, Chiba - 263-8522, Japan \\ *Corresponding author
}

\begin{abstract}
A B S T R A C T
Keywords

Polymorphism,

UPGMA,

Landraces, Genetic

variability, Genetic

conservation,

Phylogenetic

relationship

Article Info

Accepted:

20 March 2019

Available Online:

10 April 2019

Present study was conducted on genetic diversity using ISSR markers for a total of 40 landraces of little millet (Panicum sumatrense) collected from five different districts of Madhya Pradesh. Ten ISSR markers amplified total 42 loci while 32 loci showed $76.19 \%$ polymorphism. Maximum number (06) of alleles were scored by the primers UBC-807 whereas, minimum number of alleles (03) were scored by the primers UBC-816. Percentage of the number of polymorphic loci within population among the three regions, the highest frequency of polymorphism was found in the Dindori region (97.61) followed by the Betul region (80.95) and the lowest were in the Chhindwara region (40.47). Cluster analysis was estimated and a dendrogram was generated using Unweighted Pair Group Analysis (UPGMA). The highest genetic variability was observed between Amwa-38, Shivri-31 and Khaparipani-24 collected from Rewa and Dindori both of them grouped distantly. The highest PIC value (0.53) was observed by using primer UBC-853 having 06 alleles among the 40 landraces of little millets. The results indicated that ISSR marker system can be effectively used in determination of genetic relationship necessary for their conservation and breeding programs among the landraces of little millets grown in different districts of Madhya Pradesh, India.
\end{abstract}

\section{Introduction}

Little millet belongs to the family Poaceae, sub-family Panicoideae and the tribe Paniceae (Rachie, 1975). It is grown indigenously in the tropics and sub tropics. It is a drought tolerant crop and requires less amount of water to complete its life cycle. Little millet is widely distributed in temperate zone of Asia and tropical region of the world. Among Indian states, mainly Tamil Nadu, Bihar, Andhra Pradesh, Maharastra and Orrisa. In
Madhya Pradesh, a number of land races of little millet are grown widely in Rewa, Sahadol, Satna, Anuppur, Shidhi, Umaria, and Singarauli district (Jain and Singh, 2008). It is rich in vitamin $\mathrm{B}$, minerals like potassium, phosphorus, iron, zinc and magnesium. Therefore it can address nutritional sensitive agriculture, which aims at nutritional enhancement to combat the present scenario of micronutrient malnutrition (Arunachalam et al., 2005; Kundgol et al., 2014; Selvi et al., 2015). The most pre-requisite in crop 
breeding is, exploitation of genetic variability existing in the crop for yield and related traits. Various DNA-based markers systems have been applied to several plants groups for delimiting clones and to assess their level of genetic diversity. Molecular markers have been proven to be use for crop improvement and evaluation of genetic resources (Mohan et al., 1997). PCR-based molecular markers are widely used in many plant species for identification, phylogenetic analyses, population studies and genetic linkage mapping (Williams et al., 1990). The ISSR analysis is a very useful molecular tool for studying population genetics on a wide range of plant species, as well as for identifying species, cultivars, or population of the same species (Zietkiewicz et al., 1994 and Wang et $a l ., 2009)$. The present study was aimed to explore genetic variability in little millet landraces. The information on genetic variability and component analysis can be of great help in formulating appropriate breeding strategy for genetic upgradation of little millets. The present study was undertaken with the objective to analyze the genetic variability among the landraces of little millet through ISSR marker.

\section{Materials and Methods}

\section{Plant materials}

Forty landraces of little millet were collected from five different geographical regions of Madhya Pradesh. Plants were grown in polyhouse and collected the fresh young leaf samples for isolation of genomic DNA.

\section{DNA extraction}

DNA was isolated from young leaves of little millet using CTAB Protocol (Saghai-Maroof et al., 1984) with some modifications. Chemical used for the extraction of DNA were $100 \mathrm{mM}$ Tris-HCl $(\mathrm{pH} \quad 8.0), 20 \mathrm{mM}$
EDTA (pH 8.0), $0.5 \mathrm{M} \mathrm{NaCl}, 2 \%$ CTAB (Cetyl Trimethyl-Ammonium Bromide), 0.2\% $\beta$-mercaptoethanol, $\quad 2.5 \% \quad$ PVP (Polyvinylpyrrolidone), 24:1Chloroformisoamyl alcohol (IAA), 3M sodium acetate (pH4.8), Isopropanol $\left(-20^{\circ} \mathrm{C}\right), 70 \%$ ethanol, $5 \mathrm{M} \mathrm{NaCl}$. DNA quality was tested by $(0.8 \%)$ agarose gel electrophoresis and visualized under UV light.

\section{PCR analysis}

The PCR amplification procedure for amplification of DNA components and their concentration used in the ISSR. PCR reaction was prepared as described in Table 2. PCR amplification reactions volume of $20 \mu \mathrm{l}$ consisting $2 \mu \mathrm{l}$ of PCR buffer $1 \mathrm{X}, 2.4 \mu \mathrm{l}$ of $\mathrm{MgCl} 22.5 \mathrm{mM}, 0.2 \mu \mathrm{l}$ of Tag Polymerase $(5 \mathrm{Unit} / \mu \mathrm{l}) \quad 0.5 \mu \mathrm{l}$ of $\mathrm{dNTPs} 10 \mathrm{mM}, 2 \mu \mathrm{l}$ of Primer 10pM, $2 \mu \mathrm{l}$ of genomic DNA 50ng and nuclease free water was used to make up the total volume $20 \mu \mathrm{l}$. Amplifications were performed using "BIORAD T100 and Agilent Technologies Sure Cycler 8800" programmable thermal cycler with the cycling parameters that was programmed for ISSR with an initial denaturation step at $94^{\circ} \mathrm{C}$ for 4 min followed by 45 cycles at $94^{\circ} \mathrm{C}$ for 45 second, $50^{\circ} \mathrm{C}$ for $1 \mathrm{~min}$ annealing and $72^{\circ} \mathrm{C}$ for $2 \mathrm{~min}$ elongation. In the final cycle, the elongation step at $72^{\circ} \mathrm{C}$ was extended by 5 $\min$

\section{Statistical data analysis}

PCR product using ISSR primers were scored on the agarose gel as presence (1) or absence (0) of bands of molecular weight size in the form of binary matrix for the entire sample studied. The frequency of a null allele at a given locus was estimated by taking the square root of the frequency of null homozygosity (the absence of a band), which assumes that there are two alleles at a locus under Hardy-Weinberg equilibrium. Based on 
the estimated frequency of a null allele, frequency of heterozygosity $(H)$ within population $(H s)$ and all individuals $(H t)$ were calculated. The genetic differentiation among populations $(G s t)$ was calculated as $(H t$ average $H s) / H t$ (Nei 1973). Data were analyzed to obtain Jaccard's coefficients among the isolates by using NTSYS-PC Version 2.02e software (Rohlf, 1998). Polymorphic information content (PIC) values were calculated for each ISSR primer according to the formula: PIC $=1-\mathrm{R}\left(\mathrm{P}_{\mathrm{ij}}\right) 2$, where $P_{i j}$ is the frequency of the ${ }_{i}$ th pattern revealed by the ${ }_{j}$ th primer summed across all patterns revealed by the primers (Botstein et al., 1980). A dendrogram was constructed using UPGMA (Unweighted Pair-Group Method with Arithmetic Averages) with the SAHN (Sequential, Agglomerative, Hierarchical, and Nested Clustering) routine.

\section{Results and Discussion}

The marker analysis helps to understand the genetic makeup of the germplasm and also make it possible to analyze genetic diversity within species as well as between species. In the present study 40 land races of little millets (Table 1) were used for ISSR analysis with 10 random primers (Table 3) which gave scorable DNA bands and each of the 10 random primers revealed polymorphism (Table 4).

The primers produced high degree of polymorphism with an average of $76.19 \%$. Average 4.2 bands per primer were amplified. Among the 10 primers two primers viz. UBC834 and UBC-853 revealed $100 \%$ polymorphism. The percentage of polymorphism across the landraces of little millet ranged from 60-100\%. Polymorphism Information Content (PIC) was estimated for each of the 10 ISSR markers. Higher value of PIC score indicated higher polymorphism of the ISSR markers and therefore helped in selecting the best ISSR marker in phylogenetic analysis. The Highest PIC value (0.53) was observed for UBC-853 which has 04 alleles among the 40 landraces of little millets. Markers UBC834, UBC-807 also had high PIC scores with high number of alleles. Lowest PIC value (0.37) was obtained from UBC-816. Percentage of the number of polymorphic loci within population among the three regions, the highest frequency of polymorphism was found in the Dindori region (97.61) followed by the Betul region (80.95) and the lowest were in the Chhindwara region (40.47). Polymorphism was also detected within each region (Table 5). The results also showed that the Dindori region had the highest $H s$ among the four regions (0.35), while the $H s$ of the Betul region was 0.34 and Chhindwara region was 0.14 . Rewa Ht was 0.25 and Gst on these four geographic regions was 0.20 . Percentage of the number of polymorphic loci within region was the highest in the Dindori region $(97.61 \%, \mathrm{n}=22)$, second was in the Betul region $(80.95 \%, \mathrm{n}=4)$, and the third was Rewa region $(76.19 \%, \mathrm{n}=6)$, lowest was in Chhindwara region $(40.47 \%, n=4)$. The cluster analysis was carried out based on PCR amplification banding pattern of ISSR primers, pair wise genetic similarity among 40 landraces of little millet. A dendrogram was generated using Unweighted Pair Group Analysis (UPGMA) in "NTSYS-pc version 2.02e" programme (Fig. 1).

Phylogenetic relationships the Dindori region formed a genetically distinct group based on their genetic distance from the individuals in the Chhindwara, Betul, and Rewa region. The highest genetic diversity was observed in Dindori region.

The results indicated that ISSR markers have been successfully utilized for assessing the genetic diversity and revealed a remarkable molecular discrimination between the 40 landraces of little millet. 
Table.1 List of collected landraces of little millet

\begin{tabular}{|c|c|c|c|c|c|}
\hline \multirow[t]{2}{*}{ SN } & \multirow[t]{2}{*}{ Name of accessions } & \multirow[t]{2}{*}{ Collection site } & \multicolumn{2}{|c|}{ Geographical location } & \multirow[t]{2}{*}{ District } \\
\hline & & & Latitude & Longitude & \\
\hline 1 & REWKUT20171125-4 & Amwa-1 & \multirow{2}{*}{$\mathrm{N} 34,48,19$} & \multirow[t]{2}{*}{ E 82, 21, 54} & \multirow[t]{6}{*}{ Rewa } \\
\hline 2 & REWKUT20171125-6 & Amwa-2 & & & \\
\hline 3 & REWKUT20171126-1 & Pokhra-3 & \multirow[t]{2}{*}{$\mathrm{N} 34,48,19$} & \multirow[t]{2}{*}{ E 82, 21, 54} & \\
\hline 4 & REWKUT20171126-3 & Pokhra-4 & & & \\
\hline 5 & REWKUT20171126-5 & Charhai-5 & \multirow[t]{2}{*}{$\mathrm{N} 34,48,19$} & \multirow[t]{2}{*}{ E $82,21,54$} & \\
\hline 6 & REWKUT20171126-6 & Charhai-6 & & & \\
\hline 7 & CHHKUT20171127-2 & Pipariya-7 & \multirow[t]{2}{*}{$\mathrm{N} 22,3,26$} & \multirow[t]{2}{*}{ E $78,56,17$} & \multirow[t]{4}{*}{ Chhindwara } \\
\hline 8 & CHHKUT20171127-4 & Pipariya-8 & & & \\
\hline 9 & CHHKUT20171127-9 & Ghugarlakalan-9 & \multirow[t]{2}{*}{$\mathrm{N} \mathrm{22,3,26}$} & \multirow[t]{2}{*}{ E $78,56,17$} & \\
\hline 10 & CHHKUT20171127-11 & Ghugarlakalan-10 & & & \\
\hline 11 & BETKUT20171128-2 & Lahas-11 & \multirow[t]{2}{*}{$\mathrm{N} 21,54,4$} & \multirow[t]{2}{*}{ E $77,53,45$} & \multirow{4}{*}{ Betul } \\
\hline 12 & BETKUT20171128-4 & Lahas-12 & & & \\
\hline 13 & BETKUT20171128-5 & Khamla-13 & \multirow[t]{2}{*}{$\mathrm{N} 21,54,4$} & \multirow[t]{2}{*}{ E $77,53,45$} & \\
\hline 14 & BETKUT20171128-7 & Khamla-14 & & & \\
\hline 15 & DINKUT20160830-1 & Shivri-15 & \multirow[t]{5}{*}{$\mathrm{N} 22,50,35$} & \multirow[t]{5}{*}{ E $81,14,57$} & \multirow[t]{5}{*}{ Dindori } \\
\hline 16 & DINKUT20160830-2 & Shivri-16 & & & \\
\hline 17 & DINKUT20160830-3 & Shivri-17 & & & \\
\hline 18 & DINKUT20160830-4 & Shivri-18 & & & \\
\hline 19 & DINKUT20160830-5 & Shivri-19 & & & \\
\hline 20 & DINKUT20160830-6 & Sherajhar-20 & $\mathrm{N} 22,35,17$ & E $81,19,16$ & Dindori \\
\hline 21 & DINKUT20160830-7 & Sherajhar-21 & & & \\
\hline 22 & DINKUT20160830-8 & Khaparipani-22 & $\mathrm{N} 22,39,20$ & $\mathrm{E} 81,16,41$ & \\
\hline 23 & DINKUT20160830-9 & Khaparipani-23 & & & Dindori \\
\hline 24 & DINKUT20160830-10 & Khaparipani-24 & & & \\
\hline 25 & DINKUT20160830-11 & Khaparipani-25 & & & \\
\hline 26 & DINKUT20160830-12 & Khaparipani-26 & & & \\
\hline 27 & DINKUT20180219-1 & Fadki-27 & $\mathrm{N} 22,59,59$ & E $80,57,28$ & Dindori \\
\hline 28 & DINKUT20180219-2 & Aunrai-28 & N 2256,36 & E $81,4,37$ & Dindori \\
\hline 29 & DINKUT20180219-3 & Padariya-29 & $\mathrm{N} 22,3,26$ & E $78,56,17$ & Dindori \\
\hline 30 & DINKUT20180315-1 & Shivri-30 & & & Dindori \\
\hline 31 & DINKUT20180315-2 & Shivri-31 & $\mathrm{N} 22,50,35$ & E $81,14,57$ & \\
\hline 32 & DINKUT20180315-3 & Shivri-32 & & & \\
\hline 33 & DINKUT20180315-4 & Shivri-33 & & & \\
\hline 34 & DINKUT20180315-5 & Shivri-34 & & & \\
\hline 35 & DINKUT20180315-6 & Dindori-35 & $\mathrm{N} 22,56,36$ & E $81,4,38$ & Dindori \\
\hline 36 & JABKUT20180315-7 & Kundam-36 & $\mathrm{N} 23,13,7$ & E $80,21,3$ & Janalpur \\
\hline 37 & 20171125Weedy & Rewa-37 & & & Rewa \\
\hline 38 & REKUT20171125-8 & Amwa-38 & N 34, 48, 19 & E 82, 21, 54 & \\
\hline 39 & CHHIKUT20171127-12 & Ghugarlakalan-39 & $\mathrm{N} 22,3,26$ & E $78,56,17$ & Chhindwara \\
\hline 40 & BETKUT20171128-4 & Khamla-40 & $\mathrm{N} 21,54,4$ & E $77,53,45$ & Betul \\
\hline
\end{tabular}


Table.2 PCR components with their concentrations used for PCR reaction

\begin{tabular}{|c|c|c|c|}
\hline SI. & Components & Concentrations & Volume \\
\hline 1. & $10 \mathrm{X} \mathrm{PCR} \mathrm{buffer}$ & $1 \mathrm{x}$ & $2.0 \mu \mathrm{l}$ \\
\hline 2. & $25 \mathrm{mM} \mathrm{MgCl} 2$ & $2.5 \mathrm{mM}$ & $2.4 \mu \mathrm{l}$ \\
\hline 3. & $10 \mathrm{mM} \mathrm{dNTPs}$ & $200 \mu \mathrm{M}$ & $0.5 \mu \mathrm{l}$ \\
\hline 4. & Primer & $10 \mathrm{pM}$ & $2.0 \mu \mathrm{l}$ \\
\hline 5. & Tag Polymerase $(5 \mathrm{Unit} / \mu \mathrm{l})$ & 1 unit & $0.2 \mu \mathrm{l}$ \\
\hline 6. & Nuclease free $\mathrm{H}_{2} \mathrm{O}$ & For volume making & $10.9 \mu \mathrm{l}$ \\
\hline 7. & DNA & $50 \mathrm{ng}$ & $2.0 \mu \mathrm{l}$ \\
\hline
\end{tabular}

Table.3 List of ISSR primer and their sequence

\begin{tabular}{|c|c|c|}
\hline S. No. & Primer Code & Primer Sequence 5'-3' \\
\hline $\mathbf{1}$ & UBC-834 & 5'-AGAGAGAGAGAGAGAGYT-3' \\
\hline $\mathbf{2}$ & UBC-807 & 5'-AGAGAGAGAGAGAGAGT-3' \\
\hline $\mathbf{3}$ & UBC-841 & 5'-GAGAGAGAGAGAGAGAC-3' \\
\hline $\mathbf{4}$ & UBC-853 & 5'-TCT CTC TCT CTC TCT CRT-3' \\
\hline $\mathbf{5}$ & UBC-845 & 5'-CTC TCT CTC TCT CTC TRG-3' \\
\hline $\mathbf{6}$ & UBC-812 & 5'-GAG AGA GAG AGA GAG AA-3' \\
\hline $\mathbf{7}$ & UBC-816 & 5'-CAC ACA CAC ACA CAC AT-3' \\
\hline $\mathbf{8}$ & UBC-825 & 5'-ACA CAC ACA CAC ACA CT-3' \\
\hline $\mathbf{9}$ & UBC-884 & 5'-HBH AGA GAG AGA GAG AG-3' \\
\hline $\mathbf{1 0}$ & UBC-886 & 5'-VDV CTC TCT CTC TCT CT-3' \\
\hline
\end{tabular}

Table.4 Polymorphism Information Content (PIC) value of using ISSR markers among 40 landraces of little millet

\begin{tabular}{|c|l|c|c|c|c|c|}
\hline SN & Primer & $\begin{array}{c}\text { No. of } \\
\text { allele }\end{array}$ & $\begin{array}{c}\text { Monomorphic } \\
\text { band }\end{array}$ & $\begin{array}{c}\text { Polymorphic } \\
\text { band }\end{array}$ & $\begin{array}{c}\text { \% of } \\
\text { polymorphism }\end{array}$ & $\begin{array}{c}\text { Polymorphism } \\
\text { Information } \\
\text { Content (PIC) }\end{array}$ \\
\hline $\mathbf{1}$ & UBC-834 & 4 & 0 & 4 & 100 & 0.51 \\
\hline $\mathbf{2}$ & UBC-807 & 7 & 1 & 6 & 85.71 & 0.48 \\
\hline $\mathbf{3}$ & UBC-841 & 5 & 2 & 3 & 60 & 0.42 \\
\hline $\mathbf{4}$ & UBC-853 & 4 & 0 & 4 & 100 & 0.53 \\
\hline $\mathbf{5}$ & UBC-872 & 5 & 1 & 4 & 80 & 0.41 \\
\hline $\mathbf{6}$ & UBC-812 & 4 & 2 & 2 & 50 & 0.39 \\
\hline $\mathbf{7}$ & UBC-816 & 3 & 1 & 2 & 66.66 & 0.37 \\
\hline $\mathbf{8}$ & UBC-825 & 4 & 1 & 3 & 75 & 0.38 \\
\hline $\mathbf{9}$ & UBC-884 & 4 & 1 & 3 & 75 & 0.41 \\
\hline $\mathbf{1 0}$ & UBC-886 & 4 & 1 & 3 & 75 & 0.45 \\
\hline Total & & 42 & 10 & & & \\
\hline
\end{tabular}


Table.5 Genetic diversity within region

\begin{tabular}{|l|l|c|c|c|c|c|c|}
\hline SN & \multicolumn{1}{|c|}{ Region } & $\begin{array}{c}\text { Number of } \\
\text { populations }\end{array}$ & $\begin{array}{c}\text { Number of } \\
\text { individuals }\end{array}$ & $\begin{array}{c}\text { Number of } \\
\text { polymorphic } \\
\text { loci within } \\
\text { region }\end{array}$ & $\begin{array}{c}\text { \% of } \\
\text { polymorphic } \\
\text { loci within } \\
\text { region }\end{array}$ & $\begin{array}{c}\boldsymbol{H} \text { or } \\
\boldsymbol{H} \boldsymbol{t}\end{array}$ & $\mathbf{G s t}$ \\
\hline $\mathbf{1}$ & Rewa & 4 & 10 & 32 & 76.19 & 0.25 & 0.20 \\
\hline $\mathbf{2}$ & Chhindwara & 2 & 4 & 17 & 40.47 & 0.14 & \\
\hline $\mathbf{3}$ & Betul & 2 & 4 & 34 & 80.95 & 0.34 & \\
\hline $\mathbf{4}$ & Dindori & 5 & 22 & 41 & 97.61 & 0.35 & \\
\hline $\mathbf{5}$ & All locations & 13 & 40 & 32 & 76.91 & 0.34 & \\
\hline
\end{tabular}

Fig.1 Dendrogram on the basis of the ISSR marker similarity matrix data by Unweighted Pair Group Method with Average (UPGMA) cluster analysis among 40 landraces of little millet

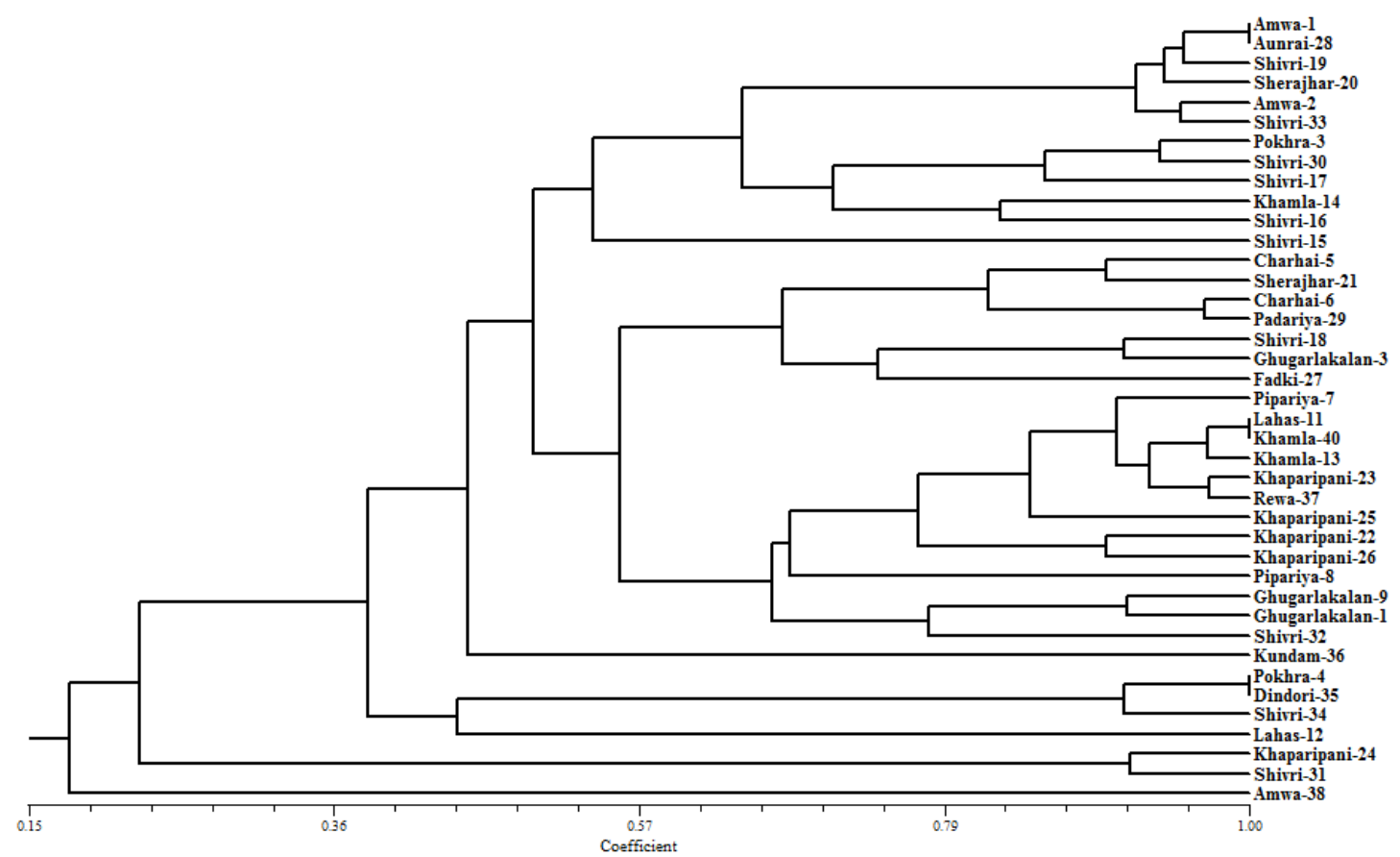

The ISSR analysis revealed the information on genetic variability and component analysis can be of great help in formulating appropriate breeding strategy for genetic relationship of among the landraces of little millets. In present investigation collected 40 landraces of $P$. sumatrense selected from various district of Madhya Pradesh viz. Dindori, Chhindwara, Betul, Rewa. The genetic diversity investigation different millets genera was undertaken with Inter Simple Sequence Repeats (ISSR) markers high level of genetic variability among and within the different genera Dvorakova et al., (2015). M'Ribu and Hilu (1994) additionally gathered three accessions for $P$. sumatrense starting with India and other Panicum sp. from different Asian nations without any confirmation of a closer relationship amongst these 26 accessions utilizing molecular 
markers, and morphologically variable (De Wet et al., 1983, Reddy et al., 1984) which is reflected by the high genetic diversity resolved by the RAPD analysis. Similarly, in present investigation, the 32 genotypes of $P$. sumatrense obtained from the region of India and evaluated genetic diversity by using out of 36 RAPD markers, high variations and $100 \%$ polymorphism among all genotypes. Molecular diversity in 7 landraces of little millet has been reported however it was also observed that the all landraces are genetically uniform and any observed diversity could be due to environmental variation Arunachalam et al., (2005). For this study, 40 landraces for $P$. sumatrense diverse districts for India with identify polymorphism utilizing ISSR marker.

Assessment of genetic variability among different landraces of little millet indicated the efficiency of ISSR markers in investigation genetic variability at molecular level and identification of desirable germplasm and its utilization for further breeding program. Such information may be useful for selecting the diverse parents and monitoring the genetic diversity periodically for improvement of little millets.

\section{References}

Arunachalam, V., Rengalakshmi, R., and Kubera-Raj, M, S. 2005. Ecological stability of genetic diversity among landraces of little millet (Panicum sumatrense) in south India. Genetic Resources and Crop Evolution. 52, 15 19.

Botstein, D., White, RL., Skolnick, M., and Davis RW. 1980. Construction of a genetic linkage map in man using restriction fragment length polymorphisms. American Journal of Human Gene 32, 314-331.

Dvorakovaa, Z., Cepkovaa, PH., Janovskab, D., Viehmannovaa, L., Svobodovaa,
E., Cusimamania, EF., and Milellac L. 2015. Comparative analysis of genetic diversity of 8 millet genera revealed by ISSR markers. Emirates Journal of food and agriculture 8: 617-628.

Jain, A., K. and Singh R, P. 2008. A profile on project report: Collection, maintenance, characterization and evaluation of land races of Small millets especially for biotic stresses in the tribal areas of Rewa division of Madhya Pradesh. College of Agriculture, Rewa (M.P.) JNKVV, Jabalpur (M.P.) 8-9.

Kundgol, N., G, Kasturiba, B., Math, K., K, and Kamatar M, Y. 2014. Kasturiba B, Math KK, Kamatar MY. Screening of little millet landraces for chemical composition. International Journal of Farm Sciences. 4, 33-38.

Mohan, M., Nair, S., Bhagwat, A., Krishna, T., G, Yano, M., Bhatia, C., R, and Sasak T. 1997. Genome mapping, molecular markers and markerassisted selection in crop plants. Molecular Breeding 3, 87-103.

Nei, M., 1973. Analysis of gene diversity in subdivided populations. Proceedings of the National Academy of Sciences. USA, 70, 3321-3323.

Rachie, KO. 1975. The millets Importance, utilization and outlook. Int. Crops Res. Inst. Semi-Arid Tropics (ICRISAT publication) Hyderabad, India.

Rohlf, FJ., 1988. NTSYS-PC numerical taxonomy and multivariate analysis system, version 1.50. Exeter Publication, Setauket, New York.

Saghai-Maroof, MA., Soliman, KM., Jorgensen, RA., and Allard RW. 1984. Ribosomal DNA spacer length polymorphism in barley: Mendelian Inheritance, chromosomal location and population dynamics. Proceedings of the National Academy of Sciences USA 81, 8014-8018. 
Selvi, M., V, Nirmalakumari, A., and Senthil N. 2015. Genetic diversity for zinc, calcium and iron content of selected little Millet Genotypes. Journal of Nutrition \& Food Sciences. 5, 1-6.

Wang, HZ., Wu, ZX., Lu, JJ., Shi, NN., Zhao, Y., Zhang, ZT., and Liu JJ. 2009. Molecular diversity and relationships among Cymbidium goeringii cultivars based on inter-simple sequence repeat (ISSR) markers. Genetica 136:391399.
Williams, JG., Kubelik, AR., Livak, KJ., Rafalski, AT., and Ingey SV. 1990. DNA polymorphisms amplified by arbitrary primers are useful as genetic markers. Nucleic Acids Research 18, 6531-6535.

Zietkiewicz, E., Rafalski, A., and Labuda D. 1994. Genome fingerprinting by simple sequence repeat (SSR)anchored polymerase chain reaction amplification. Genomics 20,176-183.

\section{How to cite this article:}

Lalit Prashad Singh Rajput, Keerti Tantwai, Sajjan Kumar Pooniya and Koji Tsuji. 2019. Assessment of Genetic Variability among the Landraces of Little Millets Panicum sumatrense from Different District of Madhya Pradesh. Int.J.Curr.Microbiol.App.Sci. 8(04): 2686-2693. doi: https://doi.org/10.20546/ijcmas.2019.804.312 